\title{
Pola Penegakan Hukum Terhadap Pelaku Pembakaran Hutan dan Lahan
}

\author{
Syaifullah Yophi Ardiyanto, Tengku Arif Hidayat \\ Author's Email Correspondence: syaifullahyophi23@gmail.com
}

\begin{abstract}
ABSTRAK
Provinsi Riau sebagai salah satu provinsi di Indonesia dengan persoalan lingkungan hidup yang cukup kompleks, khususnya persoalan kerusakan hutan dan ekosistem gambut yang dampaknya sebagai salah satu provinsi penyumbang terbesar bencana kebakaran hutan dan lahan yang terjadi di Indonesia. Kebakaran hutan dan lahan setiap tahun terus saja terjadi, namun penegakan hukum terhadap pelaku pembakaran hutan dan lahan. Penegakan hukum terhadap pelaku pembakaran hutan dan lahan menjadi hal yang sangat penting mengingat salah satu penyebab kerusakan hutan dan lahan adalah terjadinya kebakaran atau dibakarnya hutan dan lahan sebelum hutan dan lahan tersebut digunakan. Hal ini menjadi penting mengingat salah satu syarat mewujudkan Sustainable Forest Management (SFM) sangat tergantung pada kondisi kebijakan, hukum dan institusi, yang semuanya itu tercakup dalam Good Forestry Governance. Penyebab utama manajemen hutan yang buruk adalah tidak berjalannya kebijakan, hukum dan kelembagaan. Lembaga kehutanan yang lemah tidak bisa menegakkan hukum dan peraturan perundang-undangan terkait kehutanan.
\end{abstract}

\section{ARTICLE HISTORY}

Submission: 2020-09-21

Accepted: 2020-12-02

Publish: 2020-12-02

KEYWORDS: Law enforcement; offender; burning; forest; land.
Kata Kunci: Penegakan hukum; pelaku; pembakaran; hutan; lahan.

ABSTRACT
Riau Province as one of the provinces in Indonesia with
quite complex environmental problems, especially the
problem of forest destruction and peat ecosystems, the
impact of which is one of the largest contributors to the
forest and land fire disaster that occurred in Indonesia.
Forest and land fires continue every year, but law
enforcement against perpetrators of forest and land fires.
Law enforcement against perpetrators of forest and land
burning is very important considering that one of the
causes of forest and land destruction is the occurrence of
fires or burning of forests and land before the use of the
forest and land. This is important considering that one of
the requirements for realizing Sustainable Forest
Management (SFM) really depends on the conditions of
policies, laws and institutions, all of which are included in
Good Forestry Governance. The main cause of poor forest
management is the failure of policies, laws and institutions.
Weak forestry institutions cannot enforce laws and
regulations related to forestry

\section{ABSTRACT}

quite complex environmental problems, especially the problem of forest destruction and peat ecosystems, the impact of which is one of the largest contributors to the forest and land fire disaster that occurred in Indonesia. Forest and land fires continue every year, but law enforcement against perpetrators of forest and land fires. Law enforcement against perpetrators of forest and land burning is very important considering that one of the causes of forest and land destruction is the occurrence of fires or burning of forests and land before the use of the forest and land. This is important considering that one of the requirements for realizing Sustainable Forest Management (SFM) really depends on the conditions of policies, laws and institutions, all of which are included in Good Forestry Governance. The main cause of poor forest management is the failure of policies, laws and institutions. regulations related to forestry 


\section{A. PENDAHULUAN}

Hutan mempunyai kedudukan, fungsi dan peranan yang sangat penting dalam menunjang pembangunan nasional. Hal ini disebabkan karena hutan bermanfaat bagi sebesar-besarnya kemakmuran dan kesejahteraan rakyat Indonesia. ${ }^{1}$ Hutan merupakan anugerah dari Tuhan Yang Maha Esa yang tidak ternilai harganya, oleh karenanya wajib bagi kita sebagai umat manusia untuk menjaga dan melestarikannya dengan tidak melakukan kerusakan terhadap hutan, agar hutan tetap dapat memberikan manfaat tidak hanya untuk generasi sekarang tetapi juga untuk generasi yang akan datang.

Permasalahan dalam pengelolaan hutan selama ini mengakibatkan hutan dalam kondisi yang sangat mengkhawatirkan. Kerusakan hutan, penebangan liar, kebakaran dan lain sebagainya menyebabkan hutan dalam kondisi kritis. Perbaikan telah dilakukan baik dari aspek peraturan perundang- undangan dan sistem pengelolaan hutan, namun pengelolaan hutan berkelanjutan dan lestari belum juga terlaksana. Banyaknya permasalahan yang muncul di lapangan mulai dari konflik kehutanan, perizinan dan pengawasan serta korupsi kehutanan yang dilakukan oleh oknum pejabat dibidang kehutanan.

Deforestasi Indonesia pada tahun 2016-2017 tercatat 479.000 Ha. Dari catatan tersebut, luas deforestasi yang terjadi di kawasan hutan seluas 308.000 Ha dan sisanya seluas 171.000 Ha terjadi di Areal Penggunaan Lain (APL). Deforestasi yang terjadi pada 2016-2017 melanjutkan tren penurunan setelah sempat melejit pada periode 2014-2015 yang mencapai 1,09 juta Ha. Pada periode 2015-2016 deforestasi tercatat $630.000 \mathrm{Ha}^{2}$

Begitu pula yang terjadi di Provinsi Riau sebagai Provinsi dengan angka deforestasi tertinggi. Di mana Kawasan hutan di Provinsi Riau dari tahun ke tahun semakin berkurang, sedangkan deforestasi dan degradasi terhadap hutan alam di Provinsi Riau berlangsung sangat cepat. Selama kurun waktu 24 tahun (1982-2005) Provinsi Riau telah kelihangan tutupan hutan alam seluas 3,7 juta ha. Pada tahun 1982 tutupan hutan alam di Provinsi Riau masih meliputi 78\% (6.415.655 hektar) dari luas daratan Riau 8.225.199 H (8.265.556 hektar setelah dimekarkan). Hingga tahun 2005 hutan alam yang tersisa hanya 2.743.198 ha (33\% dari luas daratan Riau). Dalam kurun waktu tersebut Provinsi Riau rata-rata setiap tahun kehilangan hutan alamnya seluas $160.000 \mathrm{ha}$ /tahun dan selama periode 2004-2005 hutan alam yang hilang mencapai 200.000 ha, dan meninggalkan 22\% atau 2,45 juta ha pada tahun 2009. Data tutupan hutan tahun 2013 tersisa 2.005.512 Ha. Berdasarkan pantauan citra satelit Lansat 8 menunjukkan luas hutan Riau tersisa pada tahun 2015 sekira 1.644.862 Ha (15\% dari luas daratan Riau, padahal wilayah kawasan hutan yang harus dipertahankan minimal sebesar 30\% dari luas daratan) (Jaringan Kerja Penyelamat Hutan Riau. ${ }^{3}$ Kondisi ini sudah sangat memprihatinkan, mengingat besarnya manfaat hutan bagi masyarakat dan besarnya akibat yang ditimbulkan dari kerusakan hutan tidak hanya bagi manusia tetapi juga tumbuhan serta hewan. Luas kawasan hutan di Provinsi Riau setiap tahunnya selalu berkurang.

\footnotetext{
Salim H.S. 2013, Dasar-dasar Hukum Kehutanan, Edisi Revisi, Jakarta: Sinar Grafika, hlm. 1. www.menlhk.go.id angka deforestasi tahun 2016-2017, diunduh tanggal 10 Agustus 2020. Jaringan Kerja Penyelamat Hutan Riau (Jikalahari) 2016, dalam 14 Tahun Melawan Monopoli Pengusaha Hutan dan Lahan, Catatan Hitam Tata Kelola Hutan dan Lahan di Riau 2002-2016, Pekanbaru, hlm.125.
} 
Pengelolaan hutan di Provinsi Riau selama ini menimbulkan begitu banyak permasalahan, diantaranya pertama, mulai dari deforestasi-degradasi hutan Riau, kedua, konflik dengan masyarakat tempatan dan pencemaran/kerusakan lingkungan hidup terjadi sejak korporasi hutan tanaman industri dan perkebunan kelapa sawit beroperasi, ketiga, kerusakan hutan di Riau mengakibatkan banjir setiap musim hujan, kebakaran hutan saban kemarau dan keempat praktik korupsi merupakan awal pintu masuk praktek monopoli dan berujung pada kerusakan ekologis. Praktek pengelolaan hutan selama ini yang semestinya bisa menjamin kelestarian hutan alam di Riau namun tidak terlaksana, sebaliknya pengelolaan hutan yang berlangsung justru semakin mengancam keberadaan hutan dan masyarakat Riau.

Bencana banjir, kebakaran hutan dan lahan yang melanda Provinsi Riau merupakan suatu bukti bahwa hutan Riau yang ada saat ini tidak lagi dapat menjaga keseimbangan lingkungan. Slogan pengelolaan hutan untuk kesejahteraan masyarakat, pada kenyataannya yang terjadi justru sebaliknya. Kantong- kantong kemiskinan justru berada pada daerah-daerah di dalam dan di sekitar kawasan hutan. ${ }^{4}$

Berbicara mengenai kebakaran hutan dan lahan, Provinsi Riau sebagai salah satu provinsi di Indonesia dengan persoalan lingkungan hidup yang cukup kompleks, khususnya persoalan kerusakan hutan dan ekosistem gambut yang dampaknya sebagai salah satu provinsi penyumbang terbesar bencana kebakaran hutan dan lahan yang terjadi di Indonesia. Pasca diterbitkannya Instruksi Presiden Republik Indonesia No. 11 Tahun 2015 Tentang Peningkatan Pengendalian Kebakaran Hutan dan Lahan memang kebakaran hutan dan lahan di Riau mengalami penurunan signifikan. Namun sayangnya, upaya prioritas berupa pencegahan yang seharusnya dilakukan oleh pemerintah, masyarakat dan pihak swasta belum mampu menyasar akar permasalahan kebakaran hutan dan lahan di ekosistem gambut di Provinsi Riau yang terus saja terjadi sampai saat ini.

Kemudian pada tahun 2020, Presiden kembali menerbitkan Instruksi Presiden Nomor 3 Tahun 2020 tentang Penanggulangan Kebakaran Hutan dan Lahan menggantikan Instruksi Presiden Nomor 11 Tahun 2015 tentang Peningkatan Pengendalian Kebakaran Hutan dan Lahan. Dalam Instruksi Presiden Nomor 3 Tahun 2020 tentang Penanggulangan Kebakaran Hutan dan Lahan tersebut menginstruksikan: (1) melakukan upaya penanggulangan kebakaran hutan dan lahan di seluruh wilayah Republik Indonesia yang meliputi kegiatan: (a) pencegahan terjadinya kebakaran hutan dan lahan; (b) pemadaman kebakaran hutan dan lahan; dan (3) penanganan pasca kebakaran hutan dan lahan. (2) mengefektifkan upaya penegakan hukum terhadap tindak pidana kebakaran hutan dan lahan sekaligus pembayaran ganti rugi sesuai dengan tingkat kerusakan atau akibat yang dibutuhkan untuk biaya rehabilitasi, pemulihan kondisi hutan dan lahan, atau tindakan lain yang diperlukan serta pengenaan sanksi administrasi sesuai ketentuan peraturan perundang-undangan.

Kebakaran hutan dan lahan setiap tahun terjadi, namun penegakan hukum terhadap pelaku kebakaran hutan dan lahan dirasa masih sangat lemah dan belum berjalan optimal. Menurut Inosentius Samsul mengenai instrumen hukum penanggulangan pembakaran hutan, lahan dan polusi asap, mengatakan bahwa penegakan hukum yang ada belum mampu mengatasi permasalahan pembakaran

4 Ibid, hlm. 144. 
hutan dan lahan. ${ }^{5}$ Walaupun tahun 2019 lalu penanganan dan penegakan hukum terhadap pembakaran hutan dan lahan sudah mulai dilakukan. Tahun 2019 di Provinsi Riau, Polda Riau merilis hasil penanganan kasus kebakaran hutan dan lahan (karhutla) sepanjang tahun 2019 di Provinsi Riau melalui Kabid Humas Polda Riau Kombes Pol Sunarto menyampaikan bahwa jumlah kasus karhutla yang ditangani Polda Riau dan jajaran polres di Riau sebanyak 74 kasus yang tersebar di kabupaten dan kota. Sebanyak 74 kasus terdiri dari 72 kasus perorangan dan 2 korporasi (perusahaan). Sedangkan jumlah pelaku yang ditetapkan tersangka sebanyak 81 orang (Kompas.com.31/12/2019). Tersangka terdiri dari 77 perorangan dan 4 orang dari perusahaan. "Kemudian kasus yang sudah tahap II sebanyak 65 perkara, tahap I sebanyak 5 perkara, penyidikan 3 perkara. Selain itu, ada satu perkara yang di-SP 3 karena tersangka meninggal dunia.

Penegakan hukum terhadap pelaku pembakaran hutan dan lahan menjadi hal yang sangat penting mengingat salah satu penyebab kerusakan hutan dan lahan adalah terjadinya kebakaran atau dibakarnya hutan dan lahan sebelum hutan dan lahan tersebut digunakan. Hal ini menjadi penting mengingat salah satu syarat mewujudkan Sustainable Forest Management (SFM) sangat tergantung pada kondisi kebijakan, hukum dan institusi, yang semuanya itu tercakup dalam Good Forestry Governance.

Oleh karena itu perlu rasanya melakukan penelitian tentang Penegakan Hukum Terhadap pelaku pembakaran hutan dan lahan guna mewujudkan Sustainable Forest Management Di Provinsi Riau

Berdasarkan hal diatas, maka yang menjadi permasalahan dalam tulisan ini adalah bagaimanakah pola penegakan hukum terhadap pelaku pembakaran hutan dan lahan guna mewujudkan Sustainable Forest Management di Provinsi Riau.

\section{B. METODE PENELITIAN}

Metode penelitian yang digunakan dalam penelitian ini adalah pendekatan yuridis empiris. Yuridis yaitu mengkaji konsep normatifnya atau peraturan perundangundangan, sedangkan empiris yaitu mengkaji penegakan hukum terhadap pelaku pembakaran hutan dan lahan.

\section{PEMBAHASAN}

Hutan Indonesia, sebagai karunia dan anugerah Tuhan Yang Maha Esa yang diamanatkan kepada bangsa Indonesia, merupakan unsur utama sistem penyangga kehidupan manusia. Hutan juga merupakan modal dasar pembangunan nasional yang memiliki manfaat nyata, baik manfaat ekologi, sosial budaya, maupun ekonomi agar kehidupan dan penghidupan bangsa Indonesia berkembang secara seimbang dan dinamis. Namun pada lain pihak, suatu kebutuhan tidak terbatas untuk secara berlanjut mengeksploitasi sumber daya alam untuk memenuhi kebutuhan dasar termasuk yang subsider dan tersier juga kian terus bertambah dan tidak pernah terpuaskan. ${ }^{6}$ Salah satunya adalah, pembakaran lahan besar besaran yang selalu menjadi masalah setiap tahunnya.

5 Samsul, Inosentius, 2015, Instrumen Hukum Hukum Penanggulangan Kebakaran Hutan, Lahan dan Polusi Asap. Info Singkat Hukum, Vol. VII, No.17/I/P3DI/September/2015.

6 Tristam Pascal Moeliono, Koerniatmanto Soetoprawiro, Pengembangan dan Perkembangan Pemikiran Hukum Pertanian di Indonesia, https://ujh.unja.ac.id/index.php/home/issue/view/6 
Oleh karena itu, kebakaran hutan dan lahan menimbulkan dampak terhadap kerusakan lingkungan, sosial dan kesehatan masyarakat. Tidak hanya sekedar musnahnya ekosistem tapi kabut asap yang ditimbulkannya mengganggu kesehatan masyarakat bahkan perekonomian juga ikut terganggu. Pembakaran hutan atau lahan merupakan kejahatan yang harus diperangi secara komprehensif oleh setiap pihak. salah satu upaya untuk membalas pelaku pembakaran hutan atau lahan adalah dengan mengenakan hukuman pidana penjara dan denda semaksimal mungkin, untuk membuat jera dan menjadi pelajaran bagi masyarakat dan oknum yang lain agar tidak melakukan pembakaran hutan lagi (M. Hariyanto).

Penegakan hukum merupakan bentuk hubungan antara hukum dengan masyarakat, dimana hukum bekerja maka berpengaruh terhadap perilaku sosial masyarakat. Dalam penegakan hukum dikenal dengan sistem penegakan hukum atau criminal law enforcement, sebagai bagian dari criminal policy atau upaya penanggulangan kejahatan, maka dibutuhan dua sarana, yakni sarana penal dan nonpenal. ${ }^{7}$

Tahun 2020 ini Presiden menerbitkan Instruksi Presiden Nomor 3 Tahun 2020 tentang Penanggulangan Kebakaran Hutan dan Lahan menggantikan Instruksi Presiden Republik Indonesia No. 11 Tahun 2015 Tentang Peningkatan Pengendalian Kebakaran Hutan dan Lahan. Instruksi Presiden Nomor 3 Tahun 2020 tentang Penanggulangan Kebakaran Hutan dan Lahan tersebut menginstruksikan: (1) melakukan upaya penanggulangan kebakaran hutan dan lahan di seluruh wilayah Republik Indonesia yang meliputi kegiatan: (a) pencegahan terjadinya kebakaran hutan dan lahan; (b) pemadaman kebakaran hutan dan lahan; dan (3) penanganan pasca kebakaran hutan dan lahan. (2) mengefektifkan upaya penegakan hukum terhadap tindak pidana kebakaran hutan dan lahan sekaligus pembayaran ganti rugi sesuai dengan tingkat kerusakan atau akibat yang dibutuhkan untuk biaya rehabilitasi, pemulihan kondisi hutan dan lahan, atau tindakan lain yang diperlukan serta pengenaan sanksi administrasi sesuai ketentuan peraturan perundang-undangan.

Penegakan hukum merupakan suatu proses yang melihatkan banyak hal. Oleh karena itu, keberhasilan penegakan hukum akan dipengaruhi oleh hal-hal tersebut. Secara umum, sebagaimana dikemukakan oleh Soerjono Soekanto (Soejono Soekanto, 1983: 8), ${ }^{8}$ ada lima faktor yang mempengaruhi penegakan hukum, yaitu:

1. Kaedah hukum/peraturan itu sendiri

2. Petugas/penegak hukum

3. Fasilitas

4. Masyarakat

5. Kebudayaan

Proses penegakan hukum itu menjangkau pula sampai pada tahapan pembuatan hukum/undang-undang. Perumusan pikiran pembuat undang- undang yang dituangkan dalam peraturan perundang-undangan akan turut menentukan bagaimana penegakan hukum itu nanti dijalankan.

7 Siswanto Sunarso, Wawasan Penegakan Hukum di Indonesia, Penerbit PT. Citra Aditya Bakti, Bandung, hlm. 112. 2005.

8 Soerjono Soekanto, Faktor-Faktor Yang Mempengaruhi Penegakan Hukum, Jakarta: Rajawali Press, hlm, 8, 1983. 
Kebakaran hutan dan lahan setiap tahun terjadi, namun belum mampu menjerat pelaku dengan peraturan perundang-undangan diatas. Penegakan hukum terhadap pelaku kebakaran hutan dan lahan dirasa masih sangat lemah dan belum berjalan optimal. Upaya menangani perusakan hutan sesungguhnya telah lama dilakukan, tetapi belum berjalan secara efektif dan belum menunjukkan hasil yang optimal. Hal itu antara lain disebabkan oleh peraturan perundang-undangan yang ada belum secara tegas mengatur tindak pidana yang dilakukan secara terorganisasi. ${ }^{9}$ Menurut Inosentius Samsul mengenai instrumen hukum penanggulangan pembakaran hutan, lahan dan polusi asap, mengatakan bahwa penegakan hukum yang ada belum mampu mengatasi permasalahan pembakaran hutan dan lahan (Samsul, 2015). Walaupun tahun 2019 lalu penanganan dan penegakan hukum terhadap pembakaran hutan dan lahan sudah mulai dilakukan. Tahun 2019 di Provinsi Riau, Polda Riau merilis hasil penanganan kasus kebakaran hutan dan lahan (karhutla) sepanjang tahun 2019 di Provinsi Riau melalui Kabid Humas Polda Riau Kombes Pol Sunarto menyampaikan bahwa jumlah kasus karhutla yang ditangani Polda Riau dan jajaran polres di Riau sebanyak 74 kasus yang tersebar di kabupaten dan kota. Sebanyak 74 kasus terdiri dari 72 kasus perorangan dan 2 korporasi (perusahaan). Sedangkan jumlah pelaku yang ditetapkan tersangka sebanyak 81 orang (Kompas.com.31/12/2019). Tersangka terdiri dari 77 perorangan dan 4 orang dari perusahaan. "Kemudian kasus yang sudah tahap II sebanyak 65 perkara, tahap I sebanyak 5 perkara, penyidikan 3 perkara. Selain itu, ada satu perkara yang di-SP 3 karena tersangka meninggal dunia. Hal senada sebagaimana tergambar dalam laporan Jikalahari dibawah ini:

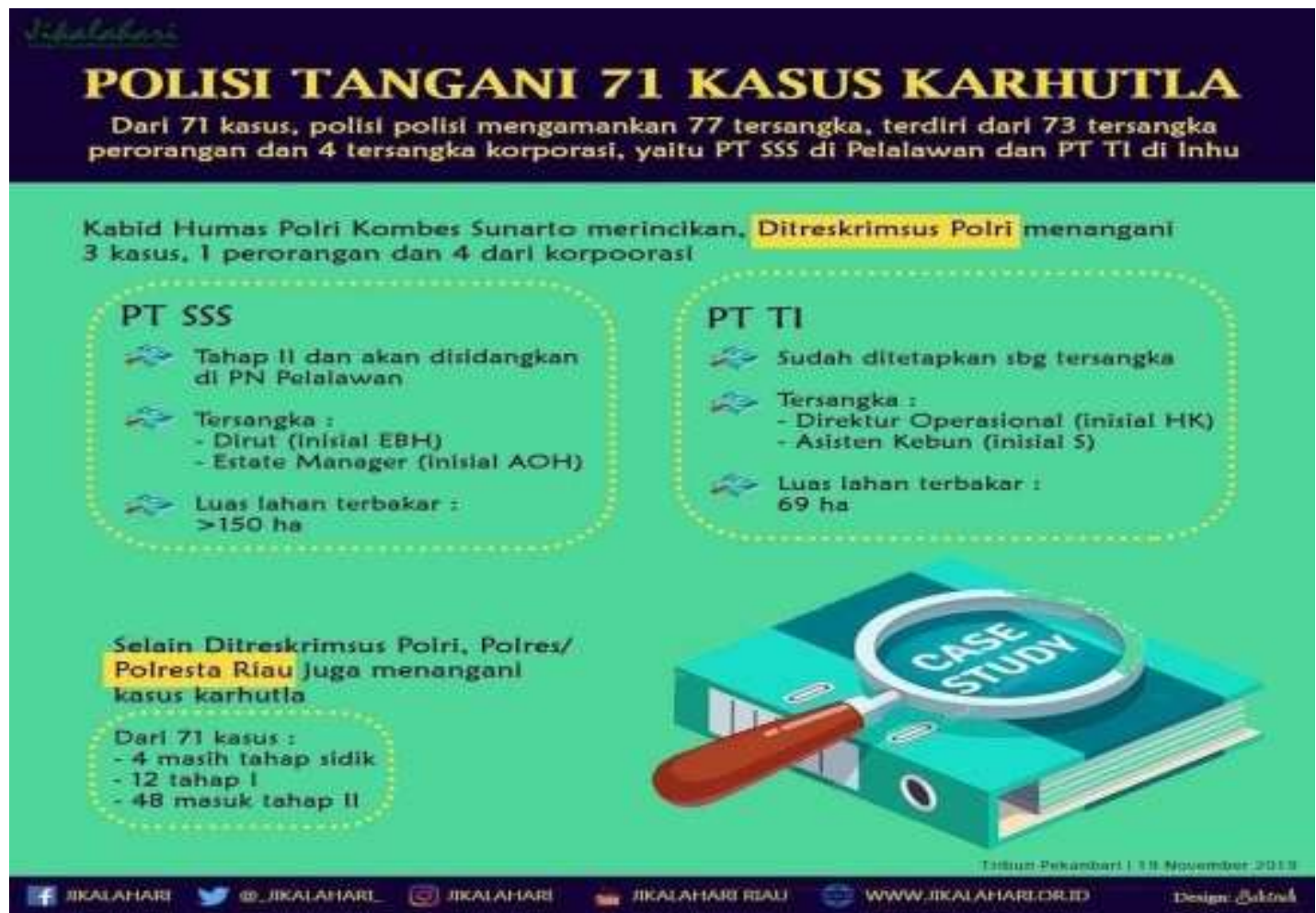

9 Sahuri Lasmadi, Elly Sudarti, Penerapan Pidana Pasal 92 Ayat (1) Huruf A Jo Pasal 17 Ayat (2) Huruf B Undang-Undang Nomor 18 Tahun 2013 Tentang Pencegahan dan Pengrusakan Hutan (Analisis Putusan Pengadilan Negeri Sarolangun Nomor: 16/PID.SUS/2015/PN.SRL) https://ejournal.undiksha.ac.id/index.php/jkh/article/viewFile/15451/9426 


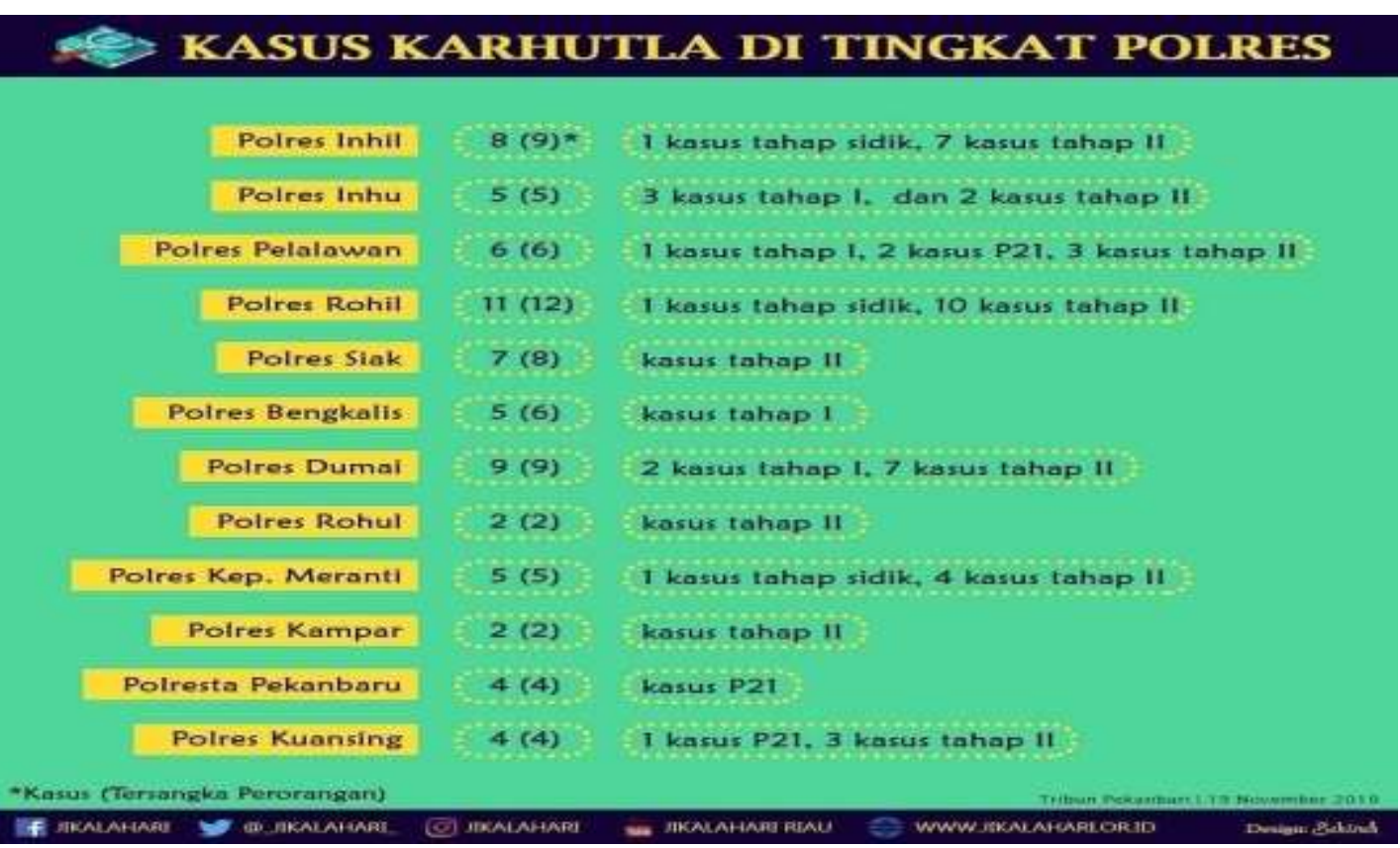

Sumber: Laporan Jaringan Kerja Penyelamat Hutan Riau (Jikalahari) Tahun 2019

Penegakan hukum pidana terhadap pelaku pembakaran hutan dan lahan di Provinsi Riau dalam rangka mewujudkan mewujudkan Sustainable Forest Management selama ini masih jauh dari harapan. Dari 74 kasus karhutla diatas, 72 kasus (97\%) pelaku pembakaran hutan dan lahan dilakukan oleh orang perorangan dengan ditetapkannya sebanyak 81 orang sebagai tersangka dan hanya 2 kasus (3\%) pelaku korporasi (perusahaan: PT SSS dan PT TI) dengan 4 orang tersangka. Sementara dari pantauan Jikalahari kebakaran hutan lahan juga terjadi pada area korporasi lainnya sebagaimana gambar dibawah ini:

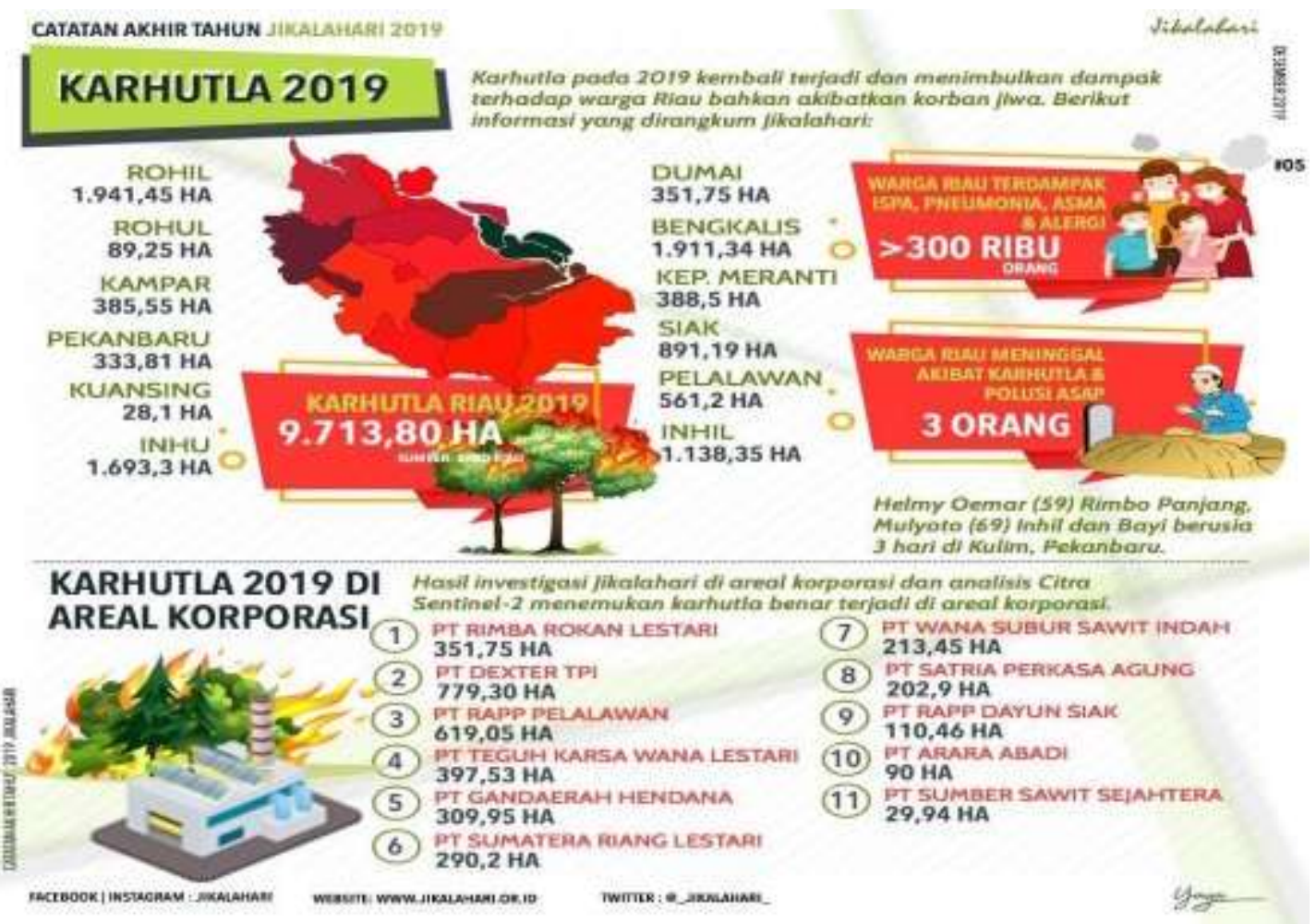




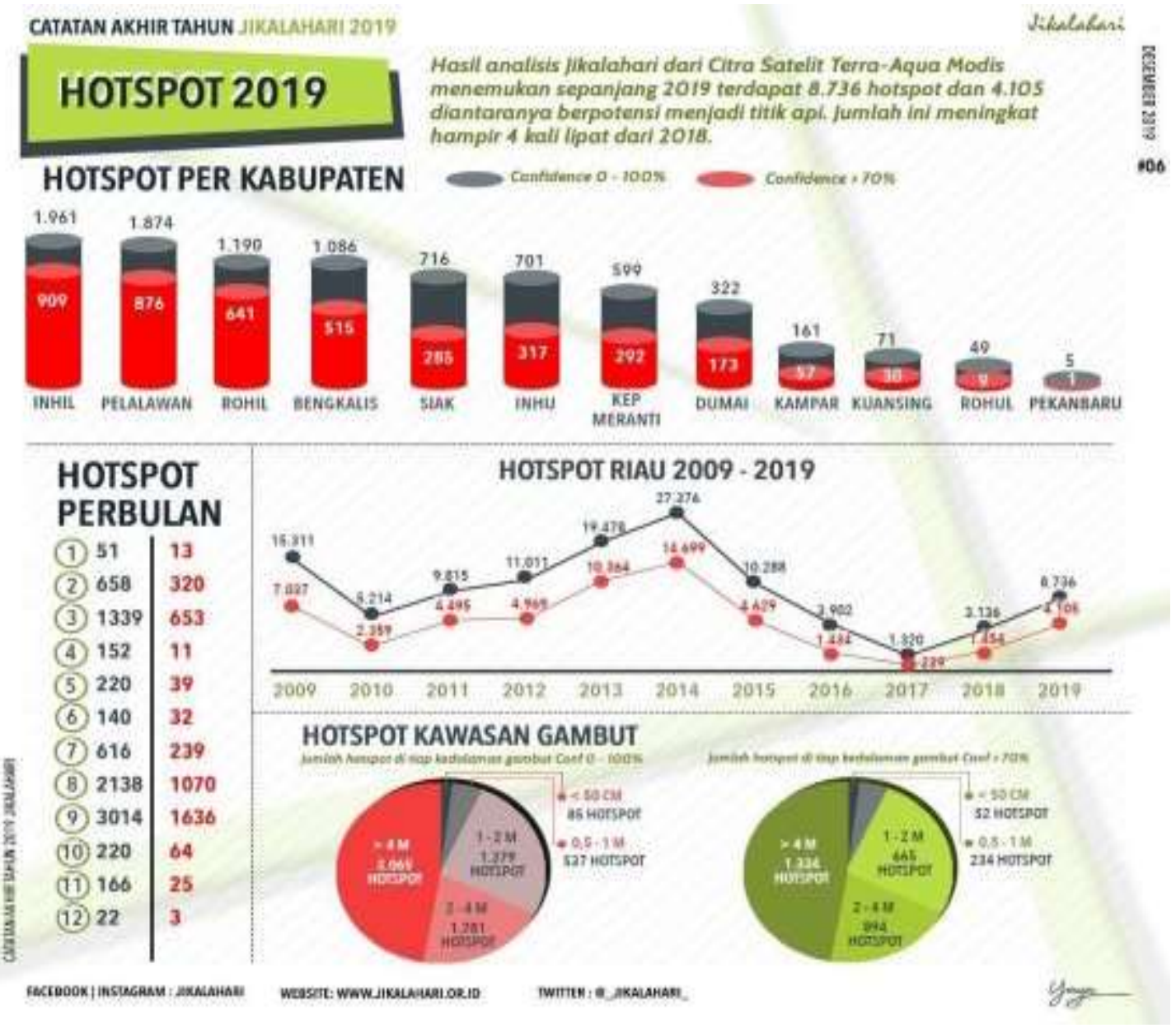

Sumber: Catatan Akhir Tahun Jikalahari Tahun 2019

Penegakan hukum pidana terhadap pelaku pembakaran hutan dan lahan (karhutla) di Provinsi Riau seperti diuraikan diatas masih didominasi orang perseorangan. Padahal ada pelaku lain yang terindikasi juga melakukan pembakaran hutan dan lahan seperti cukong, kelompok orang, pelaku usaha atau korporasi dan masyarakat. Dengan alasan penghematan biaya (biaya murah), mempercepat pekerjaan pembukaan lahan, mecegah hama dan memperbaiki kualitas tanah.

Penegakan hukum pidana terhadap orang perseorang telah berjalan sesuai dengan peraturan perundang-undangan baik itu Kitab Undang-Undang Hukum Pidana (KUHP), Undang-Undang Nomor 41 tahun 1999 tentang Kehutanan, Undang-Undang Nomor 32 tahun 2009 tentang Perlindungan dan Pengelolaan Lingkungan Hidup maupun Undang-Undang No. 39 Tahun 2014 Tentang Perkebunan. Sedangkan penegakan hukum pidana terhadap korporasi yang diindikasi melakukan pembakaran hutan dan lahan masih minim belum maksimal.

Berbicara tentang penegakan hukum terhadap pelaku pembakaran hutan dan lahan di Provinisi Riau measih mengalami hambatan. Dalam melihat penegakan hukum yang merupakan suatu proses yang melihatkan banyak hal. Oleh karena itu, keberhasilan penegakan hukum akan dipengaruhi oleh hal-hal tersebut. 
Secara umum, sebagaimana dikemukakan oleh Soerjono Soekanto sebelumnya, ada lima faktor yang mempengaruhi penegakan hukum, yaitu:

1. Kaedah hukum/peraturan itu sendiri

2. Petugas/penegak hukum

3. Fasilitas

4. Masyarakat

5. Kebudayaan

Begitu pula halnya pelaksanaan penegakan hukum pidana terhadap pelaku pembakaran hutan dan lahan di Provinsi Riau mengalami beberapa hambatan.

Secara umum, ada lima faktor yang mempengaruhi penegakan hukum:

1. Kaedah hukum/peraturan itu sendiri

Berkaitan dengan regulasi tentang sarana prasarana yang harus dimiliki korporasi untuk pencegahan kebakaran. Bahwa saat ini untuk menyatakan sebuah korporasi sengaja atau lalai melakukan pembakaran hutan dan lahan masih sulit untuk mencari regulasinya. Perlu kejelasan pengaturan dalam peraturan perundangundangan untuk memberikan kepastian hukum dan menjalankan penegakan hukum terhadap perusahaan yang terindikasi melakukan atau membiarkan terjadinya kebakaran hutan dan lahan.

2. Petugas/penegak hukum

Terbatasnya jumlah dan sumberdaya manusia dalam meningkatkan profesionalisme penegakan hukum. Dalam melakukan penegakan hukum terhadap pelaku pembakaran hutan dan lahan kemampuan dan pemahaman penyidik sangat menentukan akan keberlanjutan penanganan kasus pembakaran hutan dan lahan tersebut.

3. Fasilitas dan Kondisi Geografis Hutan di Lokasi Kebakaran

Fasilitas yang kurang memadai dan lokasi serta kondisi geografis kebakaran hutan dan lahan yang sulit dijangkau. Lokasi terjadi kebakaran jauh dari perkampungan terkadang ada di dalam hutan. Untuk menuju ke lokasi tersebut harus ditempuh berjam-jam perjalanan bahkan dengan medan yang agak sulit karena kondisi sekitar juga telah terjadi kebakaran hutan dan lahan. Dengan kondisi dan lokasi yang sulit seperti ini, terkadang menjadi penghambat bagi kepolisian untuk melakukan penyelidikan dan penyidikan terhadap pelaku pembakaran.

4. Masyarakat

Pola penegakan hukum dipengaruhi oleh tingkat perkembangan masyarakat, tempat hukum tersebut berlaku atau dibekukan. Dalam masyarakat sederhana, pola penegakan hukumnya dilaksanakan melalui prosedur dan mekanisme yang sederhana pula, namun dalam masyarakat modern yang bersifat rasional dan memiliki tingkat spesialisasi dan diferensiasi yang begitu tinggi, pengorganisasian penegakan hukumnya menjadi begitu kompleks dan sangat birokratis. Semakin modern suatu masyarakat, maka akan semakin birokratis proses penegakan hukumnya. Akibatnya yang memegang peranan penting dalam proses penegakan hukum bukan hanya manusia yang menjadi aparat penegak hukum, namun juga organisiasi yang mengatur dan pengelola operasionalisasi proses penegakan hukum.

Kondisi penegakan hukum pembakaran hutan dan lahan dalam masyarakat bukan hanya ditentukan oleh faktor tunggal, melainkan dipengaruhi oleh berbagai faktor 
yang memberikan kontribusi secara bersama-sama terhadap kondisi tersebut, namun faktor mana yang paling dominan mempunyai pengaruh tergantung pada konteks sosial dan tantangan-tantangan yang dihadapi masyarakat bersangkutan. Secara umum, faktor-faktor yang mempengaruhi penegakan hukum dalam pembakaran hutan dan lahan dapat dibedakan dalam dua hal, yakni faktor- faktor yang terdapat dalam sistem hukum dan faktor-faktor di luar sistem hukum. Adapun faktor-faktor dalam sistem hukum meliputi faktor hukumnya (undangundang), faktor penegak hukum, dan faktor sarana dan prasarana, sedangkan faktor-faktor di luar sistem hukum yang memberikan pengaruh adalah faktor kesadaran hukum masyarakat, perkembangan masyarakat, kebudayaan, dan faktor politik atau penguasa negara. Hal yang mendorong masyarakat melakukan pembakaran hutan dikarenakan faktor ekonomi dan biaya murah, mempercepat pekerjaan pembukaan lahan, mecegah hama dan memperbaiki kualitas tanah.

5. Budaya

Budaya melestarikan hutan dan menjaga hutan agar tetap lestari terkadang belum tertanam di hati sebagian masyarakat, sehingga dengan gampangnya mereka membakar hutan dan lahan hanya karena alasan biaya yang murah atau karena alasan ekonomi karena disuruh membakar hutan. Belum tumbuh kesadaran dalam diri sebagian masyarakat bahwa mencegah lebaih baik dari pada mengobati, mencegah kebakaran hutan lebih baik dari pada memadamkan kebakaran hutan yang terlanjur berdampak dan memberikan kerugian besar bagi masyarakat tidak hanya di Provinsi Riau tetapi juga masyarakt di luar Provinsi Riau.

Penegakan hukum sebagai bagian dari legal system, tidak dapat dipisahkan dengan substansi hukum (legal substance) dan budaya hukum (legal culture). Hukum sebagai gejala sosio-empiris yang dikaji kedalam variabel independen memberikan impact pada berbagai kehidupan. Aspek- aspek kehidupan sosial ini yang menjadi dependent variable. Dalam kedudukan hukum sebagai independent variable maka dapat dikaji secara law in action serta legal impact. Mengkaji hukum sebagai indepnedent variable termasuk kajian hukum dan masyarakat (law and society). Sebaliknya jika hukum dijadikan dependent variable, maka termasuk kajian sosiologi hukum (sociology of law). Perbedaan keduanya ialah kajian hukum dan masyarakat merupakan spesialisasi ilmu hukum, sedangkan sosiologi hukum merupakan spesialisasi sosiologi. Persamaannya ialah diantara keduanya tidak lagi memandang hukum sebagai suatu kaidah semata-mata dan telah merelatifkan sifat normatif-dogmatif hukum.

Pembangunan hutan berkelanjutan memerlukan upaya yang sungguh- sungguh karena masih terjadi berbagai tindak kejahatan kehutanan, seperti pembakaran hutan, pembalakan liar, penambangan tanpa izin, dan perkebunan tanpa izin. Kejahatan itu telah menimbulkan kerugian negara dan kerusakan kehidupan sosial budaya dan lingkungan hidup yang sangat besar serta telah meningkatkan pemanasan global yang telah menjadi isu nasional, regional, dan internasional.

Akhir-akhir ini perusakan hutan semakin meluas dan kompleks. Perusakan itu terjadi tidak hanya di hutan produksi, tetapi juga telah merambah ke hutan lindung dan hutan konservasi. Perusakan hutan telah berkembang menjadi suatu tindak pidana kejahatan yang berdampak luar biasa dan terorganisasi serta melibatkan banyak pihak, baik nasional maupun internasional. Kerusakan yang ditimbulkan telah mencapai tingkat yang sangat mengkhawatirkan bagi kelangsungan hidup bangsa dan 
negara. Oleh karena itu, penanganan perusakan hutan harus dilakukan secara luar biasa.

Upaya yang perlu dilakukan dalam mengatasi hambatan penegakan hukum terhadap pelaku pembakaran hutan dan lahan mulai proses penegakan hukum yang menjangkau sampai pada tahapan pembuatan hukum/undang- undang. Perumusan pikiran pembuat undang-undang yang dituangkan dalam peraturan perundangundangan akan turut menentukan bagaimana penegakan hukum itu nanti dijalankan. Peningkatan profesionalisme aparat penegak hukum, sarana dan fasilitas yang memadai, masyarakat yang sadar hukum dan budaya menjaga hutan lestari dengan cara mencegah kebakaran hutan, karena mencegah lebih baik dari pada mengobati. Lebih lanjut, menangani perusakan hutan sesungguhnya telah lama dilakukan, tetapi belum berjalan secara efektif dan belum menunjukkan hasil yang optimal. Hal itu disebabkan oleh peraturan perundang-undangan yang ada belum secara tegas mengatur tindak pidana perusakan hutan yang dilakukan secara teroganisasi. ${ }^{10}$

Sustainable Forest Management (SFM) sangat tergantung pada kondisi kebijakan, hukum dan institusi, yang semuanya itu tercakup dalam Good Forestry Governance. Penyebab utama manajemen hutan yang buruk adalah tidak berjalannya kebijakan, hukum dan kelembagaan. Lembaga kehutanan yang lemah tidak bisa menegakkan hukum.

Kelemahan dari forest governance cenderung mendasari masalah kehutanan seperti pembersihan hutan primer, penghijauan yang tidak menghormati hak-hak dan kebutuhan masyarakat lokal, pengelolaan hutan yang mengabaikan keanekaragaman hayati dan sebagainya ${ }^{11}$

Konsep pengelolaan hutan lestari didasarkan atas terpenuhinya kelestarian tiga fungsi utama hutan yaitu (Alan Purbawiyatna dkk, Vol. (1) 2: 84- 92 Desember 2011: 85: (a) Fungsi Ekologis/Lingkungan, ekosistem hutan harus mendukung kehidupan organisme yang sehat, tetap mempertahankan produktivitas, adaptabilitas dan kemampuannya untuk pulih kembali; (b) Fungsi Sosial, mencerminkan keterkaitan hutan dengan budaya, etika, norma sosial dan pembangunan. Suatu aktivitas dikatakan lestari secara sosial apabila bersesuaian dengan etika dan norma-norma sosial atau tidak melampaui batas ambang toleransi komunitas setempat terhadap perubahan; (c) Fungsi Ekonomis: Menunjukkan bahwa manfaat dari hutan melebihi biaya yang dikeluarkan oleh unit manajemen dan modal yang ekuivalen dapat diinvestasikan dari satu generasi ke generasi berikutnya.

10 Mayer J, Bass S, Macqueen D. 2002. The Pyramid. A Diagnostic and Planning Tools for Goood Forest Governance. The World Bank and WWF. http://www.ibcperu.org/doc/isis/8593,

11 Alan Purbawiyatna, dkk. Analisis Pengelolaan Hutan Rakyat Di Kawasan Berfungsi Lindung, (Analysis of Sustainability of Private Forest Management in Protection Area), Jurnal Pengelolaan Sumber Daya Alam dan Lingkungan Hidup (JPSL), Vol. 1.2. Desember, 2011. 
Pola interaksi tiga fungsi konsep pengelolaan hutan lestari tersebut sebagaimana tergambar dibawah ini:

Fungsi

Ekologis/Lingkungan

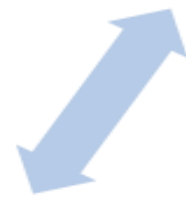

Fungsi Sosial

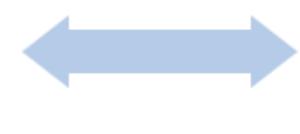

Fungsi Ekonomis

Fungsi ekologis/lingkungan dielaborasi menurut kualitas sumber daya alam, lingkungan dan keanekaragaman untuk mencapai keseimbangan pembangunan berkelanjutan maka dalam konteks hubungan antara tujuan sosial dan ekonomi diperlukan kebijakan ekonomi yang meliputi intervensi pemerintah secara terarah, pemerataan pendapatan, penciptaan lapangan kerja dan pemberian subsidi bagi kegiatan pembangunan yang memerlukannya. ${ }^{12}$

\section{SIMPULAN}

Provinsi Riau sebagai salah satu provinsi di Indonesia dengan persoalan lingkungan hidup yang cukup kompleks, khususnya persoalan kerusakan hutan dan ekosistem gambut yang dampaknya sebagai salah satu provinsi penyumbang terbesar bencana kebakaran hutan dan lahan yang terjadi di Indonesia. Kebakaran hutan dan lahan setiap tahun terus saja terjadi, namun penegakan hukum terhadap pelaku Pembakaran Hutan Dan Lahan Guna Mewujudkan Sustainable Forest Management Di Provinsi Riau masih dirasa belum maksimal. Penegakan hukum terhadap pelaku pembakaran hutan dan lahan menjadi hal yang sangat penting mengingat salah satu penyebab kerusakan hutan dan lahan adalah terjadinya kebakaran atau dibakarnya hutan dan lahan sebelum hutan dan lahan tersebut digunakan. Hal ini menjadi penting mengingat salah satu syarat mewujudkan Sustainable Forest Management (SFM) sangat tergantung pada kondisi kebijakan, hukum dan institusi, yang semuanya itu tercakup dalam Good Forestry Governance. Penyebab utama manajemen hutan yang buruk adalah tidak berjalannya kebijakan, hukum dan kelembagaan. Lembaga kehutanan yang lemah tidak bisa menegakkan hukum dan peraturan perundangundangan terkait kehutanan.

12 Tutut Ferdiana, dkk, Rekonstruksi Kebijakan Publik tentang Izin Pinjam Pakai Kawasan Hutan yang berbasis Sustainable Development, Diponegoro Law Journal, Volume 6, Nomor 3 Tahun 2017, hlm. 16. 


\section{DAFTAR PUSTAKA}

\section{Buku}

Ferdiana, Tutut dkk. Rekonstruksi Kebijakan Publik tentang Izin Pinjam Pakai Kawasan Hutan yang berbasis Sustainable Development, Diponegoro Law Journal, Volume 6, Nomor 3 Tahun 2017.

H.S., Salim. 2013, Dasar-dasar Hukum Kehutanan, Edisi Revisi, Jakarta: Sinar Grafika.

Jaringan Kerja Penyelamat Hutan Riau (Jikalahari), dalam 14 Tahun Melawan Monopoli Pengusaha Hutan dan Lahan, Catatan Hitam Tata Kelola Hutan dan Lahan di Riau 2002-2016, Pekanbaru, 2016.

Lembaga Adat Melayu Riau, Pendidikan Budaya Melayu Riau, Buku Sumber Pegangan Guru Pendidikan Budaya Melayu Riau. Pekanbaru, 2018.

Purbawiyatna, Alan dkk, Analisis Kelestarian Pengelolaan Hutan Rakyat Di Kawasan Berfungsi Lindung, (Analysis of Sustainability of Private Forest Management in Protection Area), Jurnal Pengelolaan Sumber Daya Alam dan Lingkungan Hidup (JPSL) Vol. (1) 2 : 84- 92 Desember 2011.

Samsul, Inosentius. 2015, Instrumen Hukum Penanggulangan Kebakaran Hutan, Lahan dan Polusi Asap. Info Singkat Hukum, Vol. VII, No. 17/I/P3DI/September/2015.

Sunarso, Siswanto. Wawasan Penegakan Hukum di Indonesia, Penerbit PT. Citra Aditya Bakti, Bandung, 2005.

Soejono Soekanto, Penegakan Hukum, Jakarta:Binacipta , 1983.

Soejono Soekanto, Faktor-faktor yang Mempengaruhi Penegakan Hukum, Jakarta:Rajawali Press, 1983.

Sudarto. Kapita Selekta Hukum Pidana, Alumni, 1996.

\section{Jurnal:}

Sahuri Lasmadi, Elly Sudarti, Penerapan Pidana Pasal 92 Ayat (1) Huruf A Jo Pasal 17 Ayat (2) Huruf B Undang-Undang Nomor 18 Tahun 2013 Tentang Pencegahan dan Pengrusakan Hutan (Analisis Putusan Pengadilan Negeri Sarolangun Nomor: 16/PID.SUS/2015/PN.SRL) https://ejournal.undiksha.ac.id/index.php/jkh/article/viewFile/15451/9426

Tristam Pascal Moeliono, Koerniatmanto Soetoprawiro, Pengembangan dan Perkembangan Pemikiran Hukum Pertanian di Indonesia, https://ujh.unja.ac.id/index.php/home/issue/view/6 